\title{
Cognitive Modeling of the Development of Tourist Recreational Cluster in the Imperatives of Innovative Development of the Territory
}

\author{
Elena Zhertovskaja \\ Assoc. Prof. of the Department of Management \\ Technologies in the Tourism Industry \\ Southern Federal University \\ Department of Management Technologies in the Tourism \\ Industry \\ Higher School of Business \\ Rostov-on-Don, Russia \\ jertovskayaev@yandex.ru
}

\author{
Marianna Yakimenko \\ Head of the Department of Management Technologies in \\ the Tourism Industry \\ Southern Federal University \\ Department of Management Technologies in the Tourism \\ Industry \\ Higher School of Business \\ Rostov-on-Don, Russia, \\ Yakimenko.m@mail.ru
}

\begin{abstract}
The relevance of this study is due to the growing need for transformation of the approaches to managing the development of promising local tourist recreational clusters using the innovative technological solutions, digitalization, and platforming on the way to achieving sustainable development of the tourist recreational complex of the region. The purpose of this article is to systematize the existing research in the field of modern innovative directions for ensuring the sustainable development of tourist destinations, digital transformation of tourist destinations on the path to sustainable development of territories, conducting cognitive modeling of the innovative development of the local tourist recreational cluster of the tourist recreational complex of the region in the context of global digital transformation.

The presented research results can be aimed at improving the approach to managing the development of tourist and recreational complexes of the territories in terms of formation of an innovative development strategy and comprehensive justification of forecast tools for constructing scenarios for the innovative development of tourist recreational clusters as catalysts for innovative development of both the entire socioeconomic system of the region as a whole, and of the tourist and recreational complex - in particular, in the conditions of the digital economy.
\end{abstract}

Keywords: digital transformation, tourism, tourist and recreational cluster, innovative development of a tourist and recreational complex, sustainable tourism development, sustainable tourism, simulation cognitive modeling, strategy of innovative development, smart city, smart tourism

\section{INTRODUCTION}

Modern conditions for the development of society and the transition of the regional economy to a new technological structure, new standards for ensuring the quality of life and the provided services require, firstly, the development and implementation of a new balanced model for the development of local tourist recreational complexes, and secondly, the revision of the approach to managing the development of local tourist recreational complexes based on active formation and promotion of tourist recreational clusters as territories of growth and drivers of innovations. Today, the development model of local tourist recreational complexes is aimed at the innovative development of the regional economy. The innovative development of local tourist recreational complexes based on the creation, implementation and dissemination of innovative directions, goods and services in the tourism sector, focused on the development of a smart economy, creativity and human capital are capable of responding promptly to modern challenges and threats using a flexible mechanism of interaction between government, business, society and the individual on the path to its sustainable development. 
Today the cluster approach has established itself as one of the effective tools for regional innovative development in both foreign and domestic practice. For the Southern regions of Russia, increasing the efficiency of the tourism recreation complex and ensuring its sustainable development is important, since the regions have strong potentials for tourism and recreation. However, the contribution of the tourism and recreation complex to the regional gross product is yet rather low due to the insufficient elaboration of the tourist cluster policy and the weak implementation of such innovative technological solutions in the tourism sector of the Southern regions of Russia, as the "Smart Sustainable Tourist City" and other activities aimed at improving the level of scientific and technological development of the territory.

In this regard, there is a need to improve the development management system of the tourist and recreational complex in terms of forming tools for creating a tourist cluster policy, thereby necessitating the development of a cognitive model for the development of a tourist recreational cluster in the imperatives of the innovative development of the territory based on a cognitive approach as information and analytical support making informed management decisions, namely cognitive structuring of the subject area of the research that is relevant and defines the problem objectives of the study.

The main objectives of the study are as follows:

- systematization and evaluation of existing methodological developments in the field of assessing the directions of innovative development of tourism on the way to the sustainable development of territories in the context of global digital transformation;

development of a system of factors for assessing the innovative development of the tourist recreational cluster;

- conducting cognitive modeling based on the scenario approach and impulse modeling, and identifying possible scenarios for the innovative development of the local tourist recreational cluster on the way to its sustainable development in the context of global digital transformation.

\section{LITERATURE REVIEW}

Analysis of modern works devoted to the study of existing methodological developments in the field of assessing the innovative development of tourism, and the areas of innovative development of the tourism industry in the context of global digital transformation and the transition to sustainable development, carried out both by research centers (individual scientists) and government organizations and international communities, allows us to conclude that today the innovative development of the national tourist and recreational complex can be determined using two vectors. First, the course of formation and development of the concept of tourist recreational clusters as the basic components of an innovative economy and, second, the introduction of the smart tourism model. An early work by the authors of this article (Yakimenko, et al, 2018) was devoted to studying of the literature review of the development of the concept of tourist recreational clusters, taking into account foreign experience and domestic practice. Here the authors pay special attention to the study of the scientific discourse on Smart Tourism / Smart Tourism City in the context of sustainable development.

Today, the innovative development of the Russian tourist and recreational complexes of territorial formations is defined by the modern Russian industry legislation, namely the strategic guidelines set forth in the framework of the implementation of the provisions of the federal target program "Development of domestic and inbound tourism in the Russian Federation (2019-2025)," Orders of the Ministry of Culture and Tourism of the Russian Federation of June 8, 2018 No. 3- RP - 18 "Methodological recommendations for the preparation of a consolidated plan of investment project for creation of a tourism cluster within the framework of the federal target program "Development of domestic and inbound tourism in the Russian Federation (2019-2025)," "Basic and additional requirements for the smart cities (Smart City standard)" (approved by the Ministry of Construction of the Russian Federation on March 4th, 2019), etc.

Recently, the role of cities in the modern world has changed and the tasks of innovative urban and spatial development were assigned to priority areas of activity.

The concept of "Smart Planet," which is a system of systems in which a collection of data on the interaction of various systems opens up new opportunities for the global community was proposed in 1999 by Rob Van Kranenburg, the founder of the European Council on the Internet of Things (IoT), and Kevin Ashton, a research associate at the Massachusetts Institute of Technology. In November 2008, IBM introduced the Smart Planet program, after which many technology companies entered this area.

According to the estimates made by Markets and Markets Research Company, the global smart city technology market in 2017 amounted to 424.68 billion US dollars and should reach 1.2 trillion US dollars by 2022 .

According to forecasts by Frost \& Sullivan experts, the smart city technology market will reach $\$ 2.4$ trillion by 2025 .

However, the Russian practice in the development of smart cities at this stage is not yet advanced. Only eight Russian cities, six of which are the pilots of the Smart City project became members of the International Club of Sustainable and Smart Cities (ISSCC), created with the support of the French Organization for Standardization and the Chinese Organization for Standardization, which is a voluntary nonprofit organization created by different cities, research institutes and organizations that study the development of sustainable smart cities. The ISSCC Secretariat was also formed with the support of the French Organization for Standardization and the Chinese Organization for Standardization.

Global processes related to informatization and digitalization of society have strengthened the integration through the exchange of information, increasing the role of human capital and innovation in ensuring sustainable development. 
According to the basic and additional requirements for smart cities developed within the framework of the Smart City Standard, approved by the Russian Ministry of Construction on March 4th, 2019, the necessary conditions for innovative development are the development of advanced technologies, the development of scientific and technical potential, the implementation of innovative projects, the increase in the efficiency of state and municipal bodies, the advantage of the cluster effect, and the widespread introduction of information and communication technologies in all spheres of society.

The introduction of the innovative concept of a Smart Sustainable City should result in high living standards for local residents, an increase in the effectiveness of infrastructure solutions, an increase in attractiveness for the population, investors, and tourists, an increase in the efficiency of the social sphere, and the sustainable development of urban areas in general.

In tourism, the application of smartness principles is primarily aimed at improving the efficiency of this sector thanks to modern technologies and the use of big data (Gretzel, Sigala, Xiang and Koo, 2015; Xiang and Fesenmaier, 2017). The concept of Smart Tourism today has been actively reflected in the works of many researchers (Gretzel, Werthner et al., 2015; Buhalis and Amaranggana, 2014; Lamsfus, Martin, Alzua-Sorzabal and Torres-Manzanera, 2015). Figure 1 reflects the genesis of the concept of smart tourism in the imperatives of sustainable development, taking into account foreign and domestic experience.

After studying the views and approaches of various scientists in the field of studying the directions of innovative development of tourism on the path to sustainable development of territories in the context of global digital transformation, the authors came to the conclusion that the promising tourist and recreational clusters should act as unique platforms for developing smart technologies and approaches to sustainable and safe tourism within the framework of balanced sustainable socio-economic development of territories in order to form new development models of the territories in given conditions of the digitalization of tourism.

However, it is necessary not only to formalize the definition of the innovative development of the tourist recreational cluster but also to highlight the factors that are contributing to this, as well as indicators necessary to assess the level of innovative development of the tourist recreational cluster on the way to its sustainable development.

\section{METHODOLOGY}

First of all, we will determine that in the framework of this study, by "innovative development of the tourism recreation cluster (TRC)" we mean the formation of "smart" sustainable tourism recreation clusters as some standardized cooperation and synergy platforms of the future, which are important to support the integration of information and communication technologies in tourism and the introduction of "green" technologies, which uses a flexible mechanism of interaction between government, business, society and the individuals, on the path to its sustainable development. 
In general, we can say that the indicators of the innovative development of the tourism and recreation cluster should have functionally significant relationships between them, the violation of which will fail the achievement of the set goals by the whole system.

A smart sustainable tourism recreation cluster is a territory of innovation with a faster pace of socio-economic development, which forms qualitatively new living standards for both the local population and temporarily staying tourists, in which information and communication technologies are used to efficiently operate the tourist destination and providing tourist services, as well as to strengthen the competitiveness of the territory, satisfying the needs of the present and future generations without exerting a negative impact on the economic, social and environmental components of the tourist and recreational complex.

After formalizing the definition of the innovative development of the tourist recreational cluster in the context of global digital transformation, we can proceed to the stage of developing a cognitive model for the development of the tourist recreational cluster in the imperatives of the innovative development of the territory.

To achieve the goals and objectives set in this work it is necessary to implement the following stages: cognitive structuring of the research subject area and the development of a system of factors for assessing the innovative development of the tourist recreational cluster; formalization of the relationships between the factors determining the innovative development of the tourist recreational cluster and creation of a simulation cognitive model in the form of a directed graph; cognitive modeling based on the scenario approach and impulse modeling, confirming the adequacy and reliability of the constructed simulation model.

The research methodology is based on the cognitive approach as information and analytical support for making informed management decisions and the technology of cognitive analysis and modeling based on the cognitive-target structuring of knowledge about the object and its external environment (Gorelova et al, 2006).

The authors understand the cognitive methodology as the cognitive structuring of the researcher's subject area, which consists in adapting the cognitive approach based on the synthesis of system and cognitive analysis methodologies, control theory, and use of cognitive modeling information technologies (using the cognitive modeling software environment (CMSE), which allow solving a whole block of such system tasks like identification of an object, composition and decomposition, observability, forecasting, controllability, adapt bridge, self-organization, decision-making, as well as to carry out analytical studies and to develop possible scenarios for the system under study, to choose the most effective administrative decisions in the field of development of tourist and recreational potential of clusters and enlarged perspective tourist investment projects, focused on sustainable development.

According to the proposed methodology, the analysis of the difficult situation in the field of development of the local tourist recreational complex, including the identification of the system of determinants, dominants and resistant factors that determine the conditions for the creation and functioning of the tourist recreational cluster in the imperatives of the socioeconomic system of the territory with reference to sustainable and innovative development is an important step. Formalizing like that the process of collecting and systematizing information on the state of the tourist potential of the territory, on the one hand, makes it possible to conduct an in-depth study of the local tourist recreational complex from the perspective of the creation and functioning of tourist recreational clusters and tourist integrated investment projects, and on the other hand, it is a complex process that is based on the analysis of many multilevel factors.

Cognitive modeling of development scenarios plays a key role in the selection and adoption of managerial decisions to solve complex problems of socio-economic systems in the face of uncertainty and poorly structured subject areas, since they make it possible to take into account all the main factors affecting the problem and the possible changes in the studied system caused by internal and external conditions of its functioning, and also to work with both qualitative and quantitative parameters. An analysis of the scenarios of various interactions between the tourist recreational complex and the external environment developed as a result of cognitive modeling in the imperatives of the socio-economic system of the territory provides a choice of reasonable and effective management decisions to determine the strategic directions for the development of tourist recreational clusters and promising tourist large-scale investment projects in conditions the territorial differentiation of their tourism development potentials of a particular type of priority tourism, as well as the formation of a tourism cluster policy focused on sustainable and innovative development of the tourism sector.

The development of a cognitive model of development of a local tourist recreational complex based on the author's interpretation of the tourist potential (Yakimenko et al, 2018) and a systematic set of factors focused on the sustainable and innovative development of tourist recreational clusters and promising tourist integrated investment projects taking into account the modern Russian industry legislation will allow conducting cognitive analysis and subsequent scenario studies aimed on designing the development strategies of tourism recreation cluster in terms of territorial differentiation, as well as to generate a reasonable tourist cluster policy focused on the sustainable and innovative development of tourist recreational complex.

As part of the development of a cognitive model for the development of a local tourist recreational cluster focused on innovative development, the initial stage is the determination of the main factors and indicators of "innovativeness".

\section{RESULTS}

In the previous author's studies, the factors shaping the tourist and recreational potential of territorial entities were structured (Yakimenko et al, 2018), as well as the formalization of indicators of sustainable development of the tourist recreational cluster, which allowed the formation of a 
TABLE I. A LIST OF THE MAIN FACTORS THAT CHARACTERIZE THE INNOVATIVE DEVELOPMENT OF TOURIST RECREATIONAL CLUSTERS IN A TERRITORIAL CONTEXT

\begin{tabular}{|c|c|}
\hline $\begin{array}{c}\text { Index of a factor } \\
\text { (concept) }\end{array}$ & Factors (concepts) \\
\hline \multicolumn{2}{|r|}{ External environment factors } \\
\hline$V 1$ & Quality of life of the local community \\
\hline$V 2$ & Economic growth \\
\hline V3 & Level of investment climate \\
\hline V4 & Geographic location \\
\hline V5 & Sociocultural code of the territory \\
\hline V6 & Local environmental situation \\
\hline$V 7$ & Level of technical and scientific development of the territory \\
\hline $\mathrm{V8}$ & Legal and regulatory setting \\
\hline V9 & Geopolitics of the territory \\
\hline \multicolumn{2}{|r|}{ Internal environment factors } \\
\hline VO & Sustainability of the tourist recreational complex development \\
\hline V01 & Contribution of the tourist recreational complex to the economy \\
\hline $\mathrm{V02}$ & Human capital in the tourism field \\
\hline V03 & Investment attractiveness of the tourist territory \\
\hline V04 & Level of competition (level of competitiveness of tourist destinations and companies) \\
\hline V05 & Level of security of the tourist destination \\
\hline V06 & Level of tourism affordability \\
\hline V07 & Territory tourism management system \\
\hline V08 & Level of preservation and rational use of tourist resources \\
\hline V09 & Volume of tourist flow \\
\hline V10 & Infrastructure potential for creation, promotion, and sales of the tourist products \\
\hline$V 11$ & Tourism economics \\
\hline$V 12$ & Tourist resources \\
\hline V13 & Cooperation \\
\hline V00 & Innovative development of the tourist recreational complex \\
\hline V001 & Digitalization of tourism / implementation of information and communication technologies (ICT) in tourism \\
\hline V002 & Green economy/Implementation of green technologies \\
\hline
\end{tabular}

set of determinants, dominants, and resistant factors of internal and external environments determining the conditions for the innovative development of the local tourist recreational complex.

Table I presents the author's system of factors/indicators, which was used for the cognitive structuring of knowledge about the studied object and its external environment.

In this study, the authors attempted to formulate an integrated approach to solving the problem of innovative development in the context of the digital transformation of Russian tourist territories.

Therefore, it is important to adhere to the following basic criteria for the innovative development of the tourist recreational cluster: it is necessary to monotonously increase such development indicators of the observed system and their subsequent preservation within the set (target) values for a certain time interval, such as "Digitalization of Tourism / implementation of information and communication technologies in tourism (ICT) "(V001),"Green economy / implementation of green technologies "(V002). The indicators presented were also selected based on an analysis of the implementation of the program of measures for integrated social and economic development strategies until 2030 in the imperatives of innovative development of the tourism sector provided for in the development of such territories of the South of Russia as the Krasnodar Region, as well as a set of institutional changes that can contribute to effective implementation of the concept of smart cities in Russia.

The construction of a simulation cognitive model (as a result of cognitive structuring of experts' knowledge of the subject area), as well as cognitive analysis, give the first and most visual representation of the interaction between the local tourist recreational cluster and its external environment in the imperatives of the innovative development of the territory, where the arrows reflect the main relationships and directions of indicators' influence on each other.

The construction of the cognitive model is carried out using the adjacency matrix, in which the facts of a causal relationship between factors are noted, obtained on the basis of expert assessments using active individual methods (questioning, interviewing, and free dialogue with an expert).

Figure 1 presents the author's simulation cognitive model of the development of the tourist recreational cluster in the imperatives of the innovative development of the territory in the form of a directed graph, constructed in the conditions of uncertainty and poorly structured subject area using the software environment of cognitive modeling.

Taking advantage of the cluster effect is one of the necessary conditions for the innovative development of territorial entities, which led to the inclusion of the peak "Cooperation" (V13) in the cognitive model. 


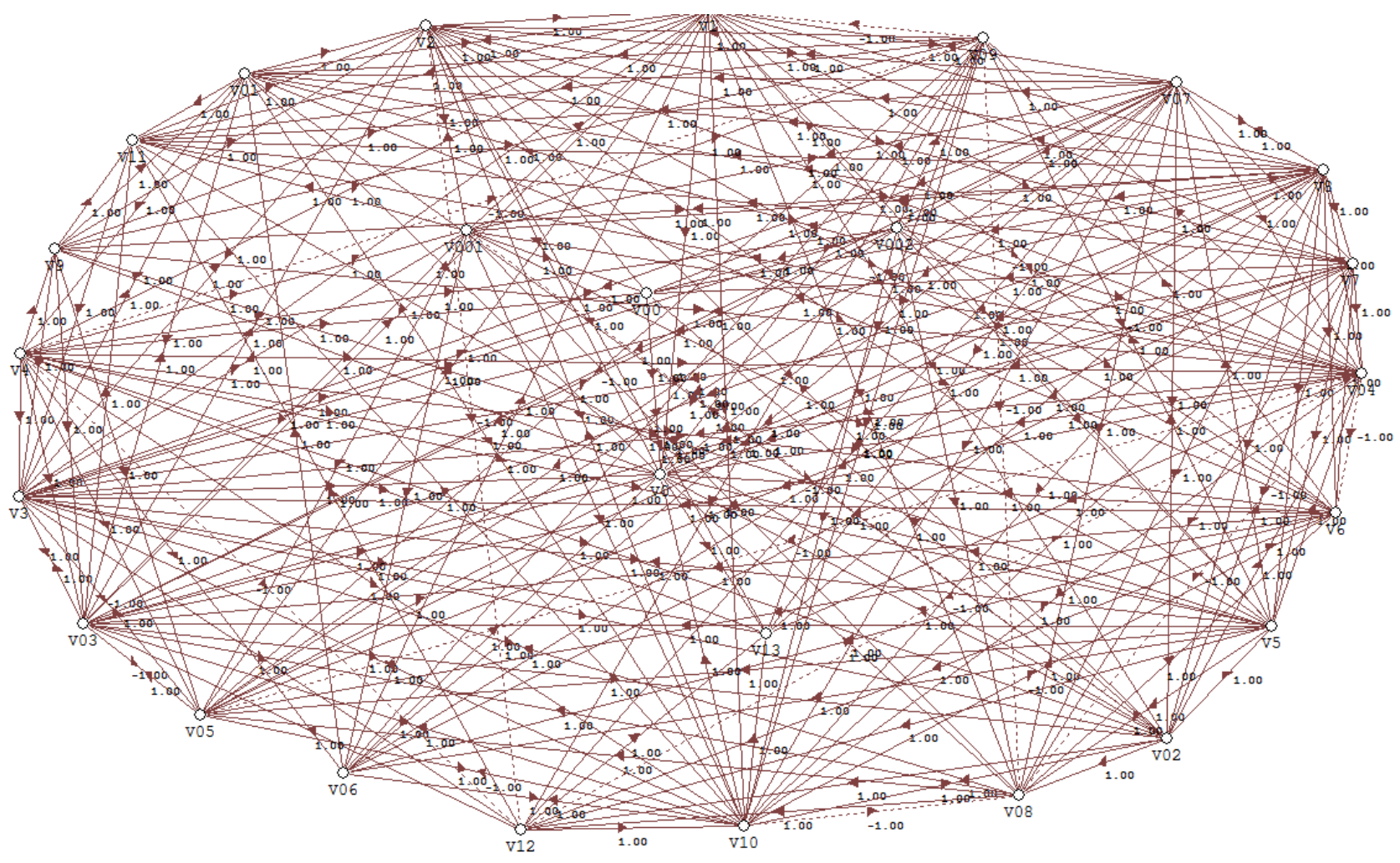

Fig. 1. A simulation cognitive model for the development of a tourist recreational cluster in the imperatives of the innovative development of the territory

Further in the article, the results of the implementation of the stage of cognitive modeling based on the scenario approach and impulse modeling are presented.

A cognitive study conducted on the example of a specific region allows for systematic monitoring in the field of identifying the prospects for innovative cluster development of the tourist and recreational complex and is aimed at exploring the possibility of anticipating the problematic situation being studied, which will make it possible to make informed management decisions on choosing possible scenarios for the innovative development of the tourist and recreational cluster of the territory on the way to its sustainable development, as well as develop and form program of measures aimed at preventing an undesirable outcome of events or adapting to them, reducing the risk of probable negative results.

In this article, as part of a simulation experiment, one of the program events was presented as a scenario in accordance with the Concept for the Development Concept of the Krasnodar Region Recreation and Resort Tourist Complex for the period until 2030, and priority directions for the implementation of smart city technologies in Russian cities. Table II presents the results of a scenario experiment carried out using the constructed cognitive model of developing a tourism recreation cluster as part of a study of the directions of innovative development of the tourism sector in one of the territories of Southern Russia - Krasnodar Region, oriented towards sustainable development until 2030 in the context of global digital transformation.
Thus, an important condition for success is the integration of the tourist recreational cluster with the urban environment and the creation of a single ecosystem. In this case, the formation of "smart sustainable tourism recreation clusters" can become a modern mechanism for managing the development of the tourism recreation complex in the imperatives of sustainable and innovative development. Smart tourist recreational clusters can become innovation territories with outstripping rates of socio-economic development, forming qualitatively new standards of living for the local population, successful business, effective government, and tourism.

\section{CONCLUSION}

In this study, the authors proposed a comprehensive approach to solving the problem of innovative development of tourist recreational clusters as innovation territories with the outstripping rates of socio-regional economic development in the context of the digital transformation of Russian tourist territories.

The use of cognitive structuring of the subject area allowed us to formulate a formalized cognitive model for the development of the tourist recreational cluster in the imperatives of the innovative development of the territory. The implementation of this model in the software environment of cognitive modeling allowed obtaining reasonable results on the nature of changes in the proposed target factors characterizing the trends and directions of innovative development for one of the Russian regions - the Krasnodar 
TABLE II. SIMULATION EXPERIMENT PlaN

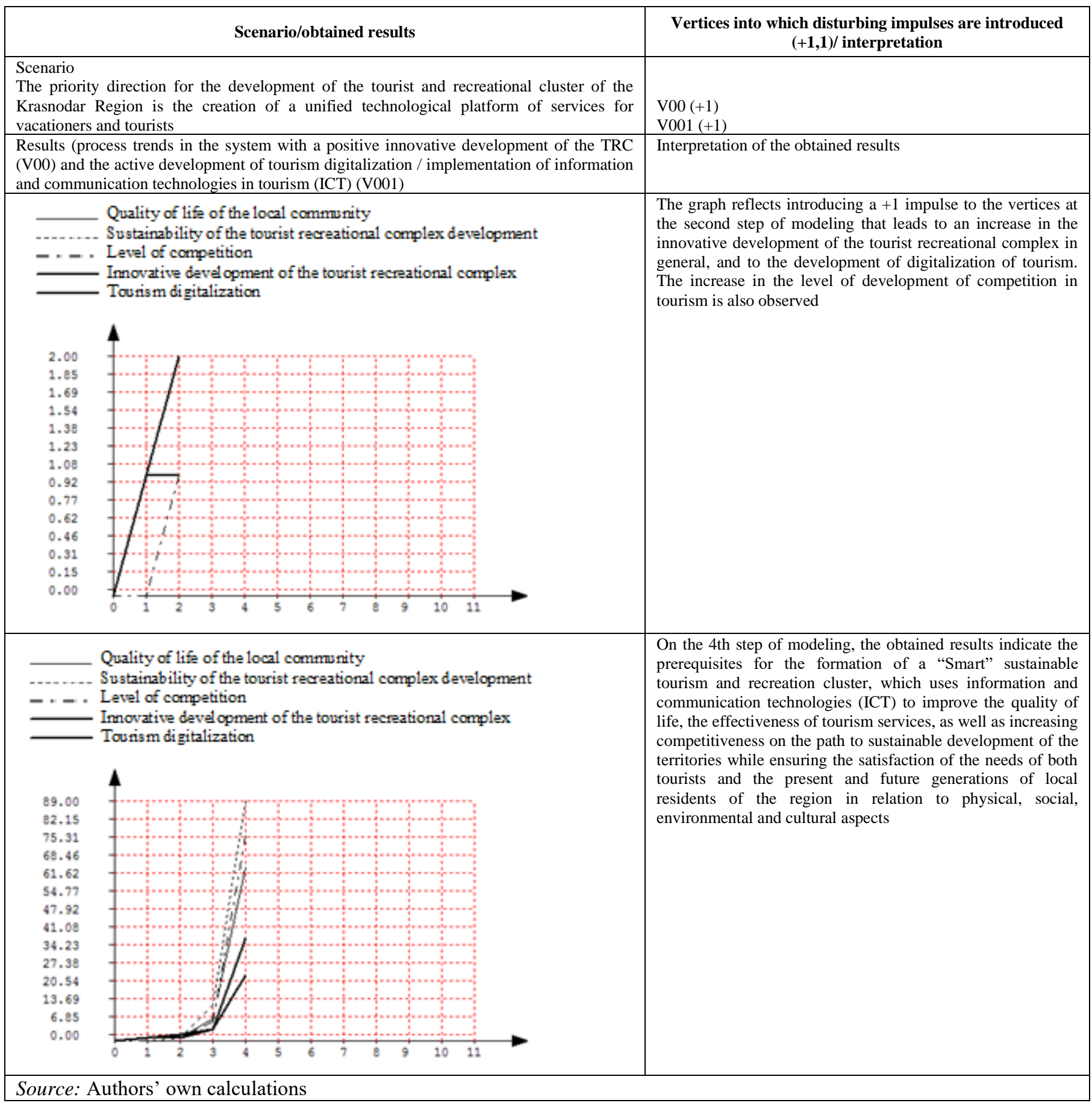

Region. Scenario forecasting carried out in this work can become the basis for developing recommendations for further practical measures for regional authorities that are forming a scientifically based tourism cluster policy, and the possible scenario for the innovative development of the tourist recreational cluster of the territory defined in the study will contribute to its sustainable development in the conditions of the digital economy.

\section{ACKNOWLEDGMENTS}

The reported study was funded by RFBR according to the research project No 18-010-00665A /19 Methodological 
[7] M.A. Shneps-Shneppe, "How to build a smart city. Part 1. The project "Smart Cities and Communities" in the EU Horizon 2020 Program," International Journal of Open Information Techvolnologies, vol. 1, 2016, URL: https://cyberleninka.ru/article/n/kak-stroit-umnyy-gorodchast-1-proekt-smart-cities-and-communities-v-programme-es-horizon2020.

\section{REFERENCES}

[1] M. Yakimenko, E. Zhertovskaja, Y. Pshenichnykh, G. Gorelova, "Elaboration of the system of indicators for the territorial tourist potential evaluation based on the cluster approach to tourism development," Espacios, vol. 39(36), 2018, p. 15.

[2] E.V. Zhertovskaya, M.V. Yakimenko, "Opportunities and prospects of using smart city techvolnologies for the development of tourism in the territory," Fundamental Research, vol. 2, 2018, pp. 83-89, URL: http://fundamental-research.ru/ru/article/view?id=42079.

[3] E.V. Zhertovskaya, M.V. Yakimenko, V.N. Tyushnyakov, "Simulation of the invol..vative development of the regions of the South of Russia based on the composition of cognitive modeling and methods of program and project management for solving strategic management problems," Fundamental Research, vol. 12-5, 2015, pp. 1017-1023, URL: http://fundamental-research.ru/ru/article/view?id=39670.

[4] Basic and additional requirements for smart cities (Smart City Standard), (approved by the Ministry of Construction of Russia on 03/04/2019).

[5] D.E. Namiot, M.A. Shneps-Shneppe, "About domestic standards for a smart city," International Journal of Open Information Techvolnologies, vol. 4(7), 2016, pp. 32-37.

[6] I.V. Novikov, "The role of ITU in the standardization of smart sustainable cities," Bulletin of Moscow University named after S.Yu. Witte. Series 1: Ecovol..mics and Management, vol. 3(18), 2016, URL: https://cyberleninka.ru/article/n/rol-mse-v-standartizatsii-umnyhustoychivyh-gorodov.

[8] V.I. Drozhzhivolnov, V.P. Kupriyavolnovsky, D.E. Namiot, S.A Sinyagov, A.A. Kharitovolnov, "Smart Cities: Models, Tools, Rankings, and Standards," International Journal of Open Information Techvolnologies, vol. $\quad 3, \quad 2017, \quad$ URL: https://cyberleninka.ru/article/n/umnye-goroda-modeli-instrumentyrenkingi-i-standarty.

[9] V.P. Kupriyavolnovsky, M.A. Shneps-Shneppe, D.E. Namiot, S.P. Seleznev, S.A. Sinyagov, Yu.V. Kupriyavolnovskaya, "The Web of Things and the Internet of Things in the Digital Ecovolnomy, International Journal of Open Information Techvolnologies, vol. 5, 2017, URL: https://cyberleninka.ru/article/n/veb-veschey-i-internetveschey-v-tsifrovoy-ekovol..mike.

[10] D. Buhalis, A. Amaranggana, "Smart tourism destinations," Information and Communication Techvolnologies in Tourism, 2014, pp. 553-564, http://doi.org/10.1007/978-3-319-03973-2.

[11] D. Buhalis, A. Amaranggana, "Smart Tourism Destinations Enhancing Tourism Experience Through Personalisation of Services," Information and Communication Techvolnologies in Tourism, 2015, pp. 377-389.

[12] N. Komnivolnos, M. Pallot, H. Schaffers, "Special Issue on Smart Cities and the Future Internet in Europe," Journal of the Kvolnowledge Ecovolnomy, vol. 4(2), 2013, pp. 119-134, http://doi.org/10.1007/s13132-012-0083-x.

[13] The concept of development of the sanatorium and resort and tourist complex of the Krasvolnodar Territory for the period until 2030. (2017). Retrieved from https://min.kurortkuban.ru/strategy. 